\title{
LEGISLATIVE AND JURISPRUDENTIAL LANDMARKS ON POSTAL VOTING
}

DOI: $10.47743 /$ rdc-2015-1-0007

Tudorel TOADER, $P h D$

Professor, Faculty of Law,

University "Al.I. Cuza” of Iaşi;

Judge, Constitutional Court of Romania

\author{
Marieta SAFTA, PhD \\ University Lecturer, Faculty of Law, \\ University "Titu Maiorescu" of Bucharest; \\ First Assistant Magistrate, Constitutional Court of Romania
}

Having examined the regulations on the matter, it is found that this voting method essentially refers to the casting of votes by mail, either directly to the appropriate electoral authority of the voter's electoral district of his/her country of origin, or to his/her country's embassy or consulate that has jurisdiction over the voter. As a general rule, ballots are mailed to voters together with an inner and an outer envelope. The filled-in ballot paper is placed in the inner envelope which is then placed in the outer envelope and sent by mail. As a main rule, the postal service is free of charge. The main advantage of postal voting consists in facilitating the exercise of the right to vote for oversees voters.

Further below, we will provide certain legislative and jurisprudential landmarks on postal voting, building on the general framework given by the constitutional rules which enshrine political rights, and particularising with examples from the case-law of certain constitutional courts which were called upon to adjudicate on the constitutionality of the regulations concerning this method for the exercise of the right to vote.

\section{The Constitution of Romania}

\section{Article 36. The right to vote}

(1) Every citizen who has attained the age of 18 years up to or on the elections day has the right to vote.

(2) Mentally deficient or alienated persons who are laid under a judicial interdiction or those disenfranchised by a final court decision may not vote.

\section{Article 37. The right to be elected}

(1) Eligibility to stand in elections is granted to all citizens with voting rights who meet the requirements set out in Article 16 para. (3), unless they are forbidden to join a political party in accordance with Article 40 para. (3). 
(2) Candidates must have turned, up to or on the elections day, at least 23 years in order to stand in elections for the Chamber of Deputies or the bodies of local public administration, at least 33 years, to stand in elections for the Senate, and at least 35 years, to stand in elections for the office of President of Romania".

\section{Article 38. The right to be elected for the European Parliament}

Once Romania has acceded to the European Union, Romanian citizens shall have the right to vote and to stand in elections for the European Parliament.

The following features of the Romanian vote have been resulted from the systematic examination of the Constitution:

- universality - consists in the fact that all Romanian citizens benefit from such right, under the conditions provided for by the framer, namely the exclusion of minors (since the participation to the political life of the State requires a certain level of maturity and responsibility), of alienated and mentally deficient persons (given the fact that, without the possibility of being legally competent for their actions, they may not vote), those who were convicted including for the ancillary punishment of disenfranchisement;

- equality - is reflected both in the number of votes granted to every citizen and in the ratio of each vote for the election of the representatives of the nation: thus, every citizen is entitled to one single vote, and that vote has the same ratio with all other votes for the election of the same State authority, regardless of the person who has exercised the right to vote;

- direct nature - refers to the fact that citizens shall vote personally and directly their representatives in Parliament, without any intermediary or proxy;

- secret nature - refers to the fact that the citizens' vote shall not be public, which constitutes one of the strongest guarantee of the voting correctness;

- free expression - refers to the fact that the expression of citizens' will in elections shall not be vitiated in any way and that the vote shall not be binding.

\section{The First Protocol to the European Convention on Human Rights}

\section{Article 3. Right to free elections}

The High Contracting Parties undertake to hold free elections at reasonable intervals by secret ballot, under conditions which will ensure the free expression of the opinion of the people in the choice of the legislature.

\section{Charter of Fundamental Rights of the European Union}

Article 39. Right to vote and to stand as a candidate at elections to the European Parliament

(1) Every citizen of the Union has the right to vote and to stand as a candidate at elections to the European Parliament in the Member State in which he or she resides, under the same conditions as nationals of that State. 
(2) Members of the European Parliament shall be elected by direct universal suffrage in a free and secret ballot.

\section{Documents of the Venice Commission}

\section{Legal value}

The Constitutional Court of Romania ruled that the documents of the Venice Commission are not binding, but "its recommendations represent the coordinates of a democratic ballot, in relation to which states - characterized as belonging to this type of regime - can express their free option in electoral matters, observing fundamental human rights, in general, and the right to vote and to stand as a candidate in elections, in particular". The Court also stated that "in fact, the Code of Good Practice in Electoral Matters is also kept as a relevant international document in the case-law of the European Court of Human Rights (for example, Judgment delivered in Case Petkov and Others vs. Bulgaria of 11 June 2009 or Judgment delivered in Case Grosaru vs. Romania of 2 March 2010)" ${ }^{1}$.

\section{Reference documents}

The main reference document in this matter, also often invoked by the Constitutional Court in its case-law, is the Code of Good Practice in Electoral Matters - Guidelines and Explanatory Report, adopted by the European Commission for Democracy through Law at its $52^{\text {nd }}$ Plenary Session (Venice, 18-19 October 2012) ${ }^{2}$, which:

a) emphasizes the principles underlying Europe's electoral heritage, i.e. "universal, equal, free, secret and direct suffrage", explaining each of such features

b) underlines the stability of electoral law, "in particular the electoral system proper, membership of electoral commissions and the drawing of consistuency boundaries". It is ruled in this regard that "it is not so much changing voting systems which is a bad thing they can always be changed for the better - as changing them frequently or just before (within one year of) elections. Even when no manipulation is intended, changes will seem to be dictated by immediate party political interests".

Underlining the same principles, Report on the timeline and inventory of political criteria for assessing an election adopted by the Council for Democratic Elections at its $34^{\text {th }}$ meeting (Venice, 14 October 2010) notes, at the same time, that "any reform of electoral legislation to be applied during an election should occur early enough for it to be really applicable to the election". However, in certain circumstances, "exceptions to the one year

\footnotetext{
${ }^{1}$ Decision no. 682/2012, published in the Official Gazette of Romania, Part I, no. 473 of 11 July 2012.

${ }^{2}$ www.venice.coe.int.
} 
rule could be accepted, namely where there is a need to rectify, through legislation, unforeseen problems or to provide redress to violations of internationally recognised rights where they had been built into the electoral law".

Regarding the voting procedures, approached in the light of the principles underlying the Europe's electoral heritage, the Guidelines establish firstly, at point 3.2. ii), the principle according to which "Voters should always have the possibility of voting in a polling station. Other means of voting are acceptable under the following conditions (...)", as they are separately provided for postal voting, electronic voting, proxy voting, the use of ballot boxes.

Thus, "postal voting should be allowed only where the postal service is safe and reliable; the right to vote using postal votes may be confined to people who are in hospital or imprisoned or to persons with reduced mobility or to electors residing abroad; fraud and intimidation must not be possible" [pct. 3.2. iii)].

Developing these principles in the Explanatory Report, at point 3.2.2.1, it is held that "Postal voting and proxy voting are permitted in countries throughout the western world, but the pattern varies considerably. Postal voting, for instance, may be widespread in one country and prohibited in another owing to the danger of fraud. It should be allowed only if the postal service is secure - in other words, safe from intentional interference - and reliable, in the sense that it functions properly. Subject to certain precautions, however, postal voting can be used to enable hospital patients, persons in custody, persons with restricted mobility and electors resident abroad to vote, in so far as there is no risk of fraud or intimidation. Postal voting would take place under a special procedure a few days before the election".

\section{Case-law of the Constitutional Court of Romania}

Due to the fact that such voting procedure is not regulated in Romania, no case-law of the Constitutional Court relates to postal voting.

However, the recitals of the decisions of the Constitutional Court of Romania became increasingly persuasive in underlying certain obligations of the legislature in electoral matters resulted from the ascertainment of numerous amendments to this law and of the shortcomings of the electoral system which were challenged during parliamentary elections in 2008 and presidential ones in 2009. In that case-law (both worth mentioning and observing any procedure of voting), the Constitutional Court underlined the need for the revision of the entire electoral law, emphasising the issues subject to review and the principles which the legislature must consider in this regard, and it also underlined the need for stability of electoral law, an expression of the principle of legal ${ }^{3}$.

\footnotetext{
3 T. Toader, M. Safta, The dialogue of constitutional judges, Universul Juridic Publishing House, Bucharest, 2015, pp. 148-151.
} 
Thus, by Decision no. 61 of 14 January $2010^{4}$, the Court held as follow: "In its work, the Constitutional Court settled more cases regarding the constitutionality of certain provisions of Law no. 35/2008 for the election of the Chamber of Deputies and the Senate, noting that the current regulation of the Romanian electoral system has certain deficiencies and, therefore, it requires its review, in the light of the parliamentary elections in 2012, in order to ensure the organization and conduct of democratic elections in Romania, in all aspects. In this regard, the Court considers it necessary, firstly, to begin with the economic, political and social facts of the country, with the role of political parties in the electoral process, with the need for the rationalization of Parliament and, finally, to regulate a ballot according to the conclusions drawn and to have a correspondent in the types of ballots used in most European states".

Likewise, the Court noted that „Law no. 35/2009, as subsequently amended and supplemented, regulates an electoral mechanism that has no connection with the elements of the uninominal majority voting, organized in one round and used in other states. It is worth mentioning that an electoral system that regulates a uninominal majority voting organized in one round provides no electoral threshold, whereas Law no. 35/2008 provides two alternative electoral threshold. The results of parliamentary elections in November 2008 revealed that such mechanism used to assign the terms of office led to non-compliant results with those specific for a uninominal majority voting. Such results were determined by mathematical calculations governed by the rules of the electoral procedure of the uninominal ballot provided for in Law no. 35/2008. Thus, the election of certain MPs was based on calculations, as such appointment did not result from elections following the expression of political options by vote".

By Decision no. 503 of 20 April $2010^{5}$, the Court allowed the exception of unconstitutionality of the provisions of Article 48(17) of Law no. 35/2008, as they eliminate from the electoral process, in case of partial elections, the independent candidacy of a person and thus, they violate the provisions of Article 37 of the Constitution - "The right to be elected".

By Decision no. 51 of 25 January $2012^{6}$, the Court allowed the objection of unconstitutionality of the Law on the organization and conduct of the elections for the authorities of local public administration and of the elections for the Chamber of Deputies and the Senate in 2012, as well as for the amendment and supplement of Title I of Law no. 35/2008 for the election of the Chamber of Deputies and the Senate, and for amending and supplementing Law no. 67/2004 for the election of local public administration authorities, Law no. 215/2001 on local public administration, and Law no. 393/2004 on the Statute of local elected officials. On that occasion, the Court critically held the frequent amendments to electoral law and noted that "Law no. 35/2008 was amended within two months following the adoption by Parliament through the Government Emergency Ordinance no. 66/2008 (...) and five months following its adoption through the Government Emergency Ordinance no. 97/2008 (...). The latter ordinance brought 92

\footnotetext{
${ }^{4}$ Published in the Official Gazette of Romania no. 76 of 3 February 2010.

${ }^{5}$ Published in the Official Gazette of Romania no. 353 of 28 May 2010.

${ }^{6}$ Published in the Official Gazette of Romania no. 90 of 3 February 2012.
}

REVISTA DE DREPT CONSTITUTYIONAL 
amendments and supplements to the law, while the law initially adopted by Parliament in compliance with Articles 75 and 76 para. (1) of the Constitution included 76 articles and one addendum on electoral constituencies". At the same time, ruling that "the right to free elections requires the observance of certain requirements, including that of stability of legal rules in the electoral field", namely that "the stability of these rules is an expression of the principle of legal certainty, set, implicitly, by Article 1 para. (5) of the Constitution", and noting that such an unexpected legislative amendment "can create additional difficulties to the other authorities entrusted with its enforcement, in terms of adapting to the newly established procedure and the technical operations it requires", namely that "this regulation is likely to determine difficulties in exercising the right to vote, difficulties which can finally result in the restriction on the exercise of this right", the Court ascertained the unconstitutionality of the impugned law. The recitals of this decision also took into consideration the Code of Good Practice in Electoral Matters, adopted by the Venice Commission. This act reveals that the stability of law is crucial to the credibility of the electoral process, and the frequent change of rules and their complex nature may confuse voters, and that it is not so much changing voting systems which is a bad thing, as changing them frequently or just before (within one year of) elections. Taking into consideration the recitals of Decision no. 61/2010, the Court stated again that "the current regulation of the Romanian electoral system has certain deficiencies and, therefore, it requires its review, in the light of the parliamentary elections in 2012, in order to ensure the organization and conduct of democratic elections in Romania", underlying "the need for the revision of the entire electoral law on elections to the Chamber of Deputies and the Senate, the President of Romania, the elections for the European Parliament, as well as the elections of local public administration authorities, which shall be comprised in an electoral code whose specific and common provisions shall ensure the organization of a democratic, fair and transparent ballot in compliance with the constitutional principles" (Decision no. 51/2012).

All these principles and recitals are also stated by Decision no. 682/2012, when the Court allowed the objection of unconstitutionality and found that the Law amending and supplementing Law no. 35/2008 for elections to the Chamber of Deputies and the Senate and amending and supplementing Law no. 67/2004 for the election of local public administration authorities, Law no. 215/2001 on local public administration and Law no. $393 / 2004$ on the Statute of the local officials is unconstitutional.

\section{Landmarks of comparative law}

For instance, in Germany ${ }^{7}$, the federal electoral law regulates postal voting as the method for the exercise of the right to vote where the ballots are mailed to oversees voters who have applied for registration, and once the vote has been cast, they are returned, by

\footnotetext{
${ }^{7}$ Summary on the basis of the study Postal voting - Case study - Federal Republic of Germany, published in Electoral Expert Review no. 4/2014, pp. 53-55.
} 
mail, in the country. Only the voters who are registered in the electoral roll or hold a voter card shall vote. In order to exercise postal voting, citizens shall submit an application to be issued a voter card. Voter cards shall be sent to the voter's residence, accompanied by the following documents in order to cast postal voting: an electoral ballot, a postal voting envelope, postal-ballot return envelope, on which there are written the return address, the local or municipal authority which issued the voter card, the number of the voter card or of the electoral district; voting instructions - all according to the official model. The voter shall send to the electoral official of his/her constituency, according to his/her voter card, an official outer sealed envelope containing his/her signed voter card and the electoral ballot which was placed in an inner sealed envelope. The envelope must reach its recipient until six o'clock p.m. on the day of the elections at the latest. The voter card should be marked with the mention that the electoral ballot has been personally executed or according to the voter's will. Such mention shall be tantamount to an oath taken before the electoral official of the appropriate constituency. The transmission is achieved through any postal service agreed, officially announced before elections. Likewise, the envelope containing the above-mentioned documents may also be handed to an appointed authority defined by law. The experiences of the past electoral years in countries with a long tradition on the matter have also been reflected in the amendment to the law of reference, being equally useful as landmarks. Thus, for instance, in Mexic, the most significant amendments concern a simpler voting procedure, the implementation of an assistance programme and free charges for sending postal envelops. As a consequence of such legislative amendments, it has been recorded an increase in the number of the registered voters, in the cast votes and in the valid applications ${ }^{8}$.

It is also worth mentioning regulations aimed at removing the disadvantages of postal voting which are underlined by the very critics of this method for the exercise of the right to vote $^{9}$. Such a disadvantage consists in the risk that the ballot paper does not reach the recipient in time to be counted. For instance, in Australia and in several states of the United States of America, postal ballots are still valid and counted even if received within a specified period after election day. Another underlined disadvantage is given by the uncertainty regarding the person who casts the vote. Therefore, some states require that the application for registration as an absentee voter be notarized and some states require a witness to sign the outer, transmittal envelope attesting to the fact that the voter placed the voted ballot in the sealed inner envelope. In Canada, the voter is required to submit, together with the application for overseas absentee voting, a photocopy of his/her passport or birth certificate as proof of Canadian citizenship. In Spain, proof of identity and the certificate of inclusion in the electoral census must be mailed together with the postal ballot.

\footnotetext{
${ }^{8}$ Further, see Erika P. Salas Rueda, Mexico: a glance on its alternative voting models, in Electoral Expert Review no. 1/2015, pp. 6-23, available on http://www.roaep.ro/prezentare/wp-content/uploads/ 2015/03/Expert_Electoral_nr.1_din_2015.pdf.

${ }^{9}$ Further, for a comparative study for a part of the above-mentioned states, see Henry S. Rojas, A Comparative Study of the Overseas Voting Laws and Systems of Selected Countries, available on pdf.usaid.gov/pdf_docs/Pnada596.pdf.
}

REVISTA DE DREPT CONSTITUT,IONAL 
The law on the matter has been differently regarded by constitutional courts. For instance, in Turkey, the new regulations which introduced postal voting have been considered as incompatible with the provisions of the Constitution. Thus, the Court has been referred to by the main opposition party parliamentary group to assess the compliance of the phrase „postal voting”, introduced in the electoral law. As grounds for the referral, it has been argued that postal voting leaves individual voters vulnerable to the influence of family members and social groups such as religious or ethnic communities. The parliamentary group also pointed out that postal voting is very open to electoral fraud, and as a result, the above provisions were contrary to Articles 2, 11, 67 and 79 of the Constitution. The Constitutional Court stated that the right to vote is a constitutional right that should be respected, whether a citizen lives in his or her homeland or overseas. That right should, however, be exercised in accordance with constitutional principles such as free, equal, secret and direct and universal suffrage, and public counting of votes. All these are contained in Article 67.2 of the Constitution of Turkey. The Court ascertained the unconstitutionality of the phrase „postal voting”, in Articles 94.A and 94.B of Law no. 298 on the General Principles of Elections and Electoral Register and held that postal voting regulated by the provisions in dispute was very far from guaranteeing secret and free voting in elections, and was contrary to Article 67 of the Constitution (Decision no. E. 2008/33, K. 2008/133 of May $2008^{10}$ ).

A thorough analysis of this voting method was made by the Constitutional Tribunal of Poland, so we will quote further below an excerpt from the decision which adjudicated on the constitutionality of the impugned rules.

Three types of allegations were brought before the Constitutional Tribunal of Poland, concerning postal voting, respectively:

- voting away from the polling station of a district electoral commission infringes the principle of the secret ballot (...);

- sending ballot papers; the applicants note that the intermediaries in the process of sending ballot papers are "postal institutions which carry out their activity in foreign countries, and whose efficiency and reliability, including the level of protecting the secrecy of correspondence and the degree of being "watertight» when it comes to persons and institutions that may be interested in affecting the results of Polish elections or in violating their secrecy, including secret services, varies in different countries (...). In those circumstances, Polish public authorities are unable to guarantee that ballot papers will reach a given voter in time and will be served on him/her, that the ballot paper in a return envelope will be filled in by a given voter himself/herself, that its content will not be seen by any outside persons during the transfer from the voter to a consul, that those persons will not resort to fraud consisting in changing the content of the ballot paper or replacing it, and that eventually it will reach the consul in time" (pp. 29-30 of the application). For these reasons, the applicants conclude that postal voting does not guarantee the fair exercise of citizen's right to vote, and thus is inconsistent with Article 62 para. (1) of the Constitution;

10 Published on the website $w w w . c o d i c e s . c o e . i n t$.

A C T U A L I T Ă Ţ I C ONST I T U Ţ IONALE 
- as part of postal voting, ballot papers are filled in several or over a dozen days before the day of elections. The applicants refer to this phenomenon as "electoral false start".

The Tribunal essentially held as follows:

- on the substantiation of this method for the exercise of the right to vote: "Postal voting makes it possible to cast votes by voters staying abroad who frequently have problems with arriving at district electoral commissions, due to the distance from those commissions to their place of residence or stay. (...) The said method of voting is admissible in many European states. Statutory regulations in that regard reveal numerous differences. In some states, postal voting is only provided for citizens staying abroad (e.g. Italy or the Netherlands), and in others - for citizens who live in their own country, but who, for various reasons, may not cast their votes in person at a polling station in their country (e.g. Germany or the Great Britain). There are also countries which have completely withdrawn from the possibility of postal voting, which had been previously introduced (e.g. France in 1975). (...)".

- on the legal framework on the matter: "The issue is dealt with in Chapter 8 of the Electoral Code, entitled "Postal voting in polling districts established abroad». It follows from Article 62 of the Electoral Code that the said method of voting is reserved for a narrow group of voters, i.e. those who are staying abroad and are included in the list of voters prepared by a consul who has territorial competence in that regard. Postal voting has an optional character, as voters who belong to that group may also cast their votes in person at a polling station set up outside the borders of the Polish state. The intention to cast a postal vote should be notified by voters to a consul who has territorial competence in that regard until the $15^{\text {th }}$ day before the day of elections [Article 63 para. (1) of the Electoral Code]. Forthwith after receiving ballot papers form a competent electoral commission, however no later than until the $10^{\text {th }}$ day before the day of elections, the consul sends a ballot package containing an addressed return envelope, a ballot paper or ballot papers, an envelope for the ballot paper or ballot papers, a statement about voting in person and in secret, as well as voting instructions [Article 65 para. (1) of the Electoral Code]. Under the heading "Annotations" in the list of voters, corresponding to the entry of the last name of a given voter who expressed his/her intention to cast a postal vote, the consul adds information about sending the ballot package to the voter [Article 65 para. (4) of the Electoral Code]. Voters who cast postal votes, after filling in ballot papers, put the papers in envelopes for ballot papers which they seal, and then they place the envelopes inside return envelopes together with signed statements, and send them at their own expense to the address of the competent consul [Article 66 para. (1) of the Electoral Code]. The consul transfers the return envelopes to the competent district electoral commission no later than on the $3^{\text {rd }}$ day before the day of elections [Article 66 para. (2) of the Electoral Code]. The return envelopes transferred by the consul are placed in the second ballot box, which is prepared solely for that purpose. The return envelopes transferred to the district electoral commission after the close of poll are destroyed without being opened. (...)".

- on the first allegation formulated by the applicants: "According to the first allegation formulated by the applicants, voting away from a polling station infringes the principle of the secret ballot. The said principle implies that no-one else but voters themselves know the

REVISTA DE DREPT CONSTITUTTIONAL 
content of their individual voting decisions. Secret ballot is a necessary guarantee of unrestrained expression of individual electoral preferences. Also, in a certain way, it protects voters from possible effects of voting, regardless of the fact whether those effects would have a positive or negative character. For voters, secret ballot is a privilege, but not an obligation. (...)

The Tribunal states that in the case of postal voting it is voters who become obliged to guarantee the secrecy of the act of voting. The obligation to guarantee the secrecy of the voting decision that has been taken is transferred from the voter to the consul at the moment of delivery of the ballot papers to the consul. Such a manner of regulating the procedure for voting away from the polling station of a district electoral commission does not infringe the principle of the secret ballot, as the legislator has indicated persons who are responsible for the implementation of the said principle at particular stages of the electoral process and created the above-mentioned complex mechanism which guarantees that the content of the voting decision of a particular voter will not be made known to third parties".

- on the second allegation formulated by the applicants: "Another concerns the issue that sending ballot papers via the postal service in foreign countries, where Polish authorities may not carry out any supervision, does not guarantee the reliable exercise of citizens' active electoral rights, and thus is inconsistent with Article 62 para. (1) of the Constitution. In the applicants' opinion, due to possible irregularities and electoral fraud that may occur during sending ballot papers, the outcome of voting may not reflect the actual preferences of voters.

It follows from the formulation of the allegation that-according to the applicants - the mere fact of sending ballot papers in the territory outside the jurisdiction of the Republic of Poland determines the unconstitutionality of the challenged provisions. The applicants a priori assume that, at that stage of electoral process, there will be irregularities which Polish authorities will not be able to prevent or counteract. Therefore, the said allegation concerns the realm of application of law, and the verification of the validity of the allegation requires the knowledge about the functioning of the challenged provisions (...). Irregularities discovered in the course of applying the procedure for postal voting would be of significance only if they occurred on such a scale that they would result in a permanent distortion of those provisions. In the present case, the applicants have not made it probable that electoral irregularities may occur on such a scale. Thus, the presumption of constitutionality of the challenged provisions has not beent refuted".

- on the third allegation formulated by the applicants: "The last allegation concerns the issue that in postal voting voters cast their votes at least a few days before the day of elections, which infringes the requirement to hold elections on a single day [Article 98 para. (2) and (5) as well as Article 128 para. (2) of the Constitution].

In the case of postal voting, the procedure for casting votes is indeed extended in timebeginning with the moment of sending a ballot paper in a ballot package by the consul, then filling it in by a voter and sending it back to the consul, until the moment of placing it in a ballot box (together with the whole return envelope). The last-mentioned action, although it 
is not done directly by the voter, but by the members of a district electoral commission, may only take place on the day of elections.

Due to this extended-in-time procedure for postal voting, it should be considered at which point in postal voting voters cast their votes in elections. Undoubtedly, voters make their choice by filling in ballot papers, writing the "X» mark in the box to the left of the name of a candidate or candidates. Filling in a given ballot paper properly guarantees the validity of a vote; however, it is not a prerequisite for casting the vote. Indeed, the vote is cast at the moment of placing the ballot paper in a ballot box, but -for the effectiveness of that action - it is irrelevant whether the ballot paper has been filled in or not. If a voter, in person, places a ballot paper which s/he has not filled in a ballot box, this will also be a form of casting a vote, although the vote will be regarded as invalid during the counting of votes conducted by a district electoral commission. On the other hand, if the voter fills in the ballot paper, and then - instead of placing it in a ballot box - it will destroy it or take it away from a given polling station, this will not be regarded as casting the vote in elections.

For that reason, the Tribunal states that casting votes in elections occurs not at the moment of filling in ballot papers by voters, but at the moment of placing them in a ballot box. The said rule applies both to voters voting at a polling station as well as to voters voting by post. In the case of the last actions, the action of filling in ballot papers precedes the action of placing them in a ballot box. However, what determines that a vote is cast is the latter action, which takes place on the day of elections. This means that the allegation about voting before the day of elections in the case of voters who vote by post is groundless" (Decision of 20 July $2011^{11}$, no. ref. $\mathrm{K} 9 / 11^{* 1}$ ).

We also refer to a decision of the Federal Constitutional Court of Germany which emphasizes the dynamic of amendments to the law on the matter, in terms of its simplification, and we are to quote a part of its summary.

In this case, the author of the referral contended that the legislative amendment which led to the lack of need to state reasons for participating in the postal ballot results in a lack of security against falsification and the heightened risk of inadvertently casting invalid votes in the postal ballot. Under the previous law, a person could only receive the ballot paper necessary to cast a postal vote if he or she, on the day of the election, was outside his or her constituency for an important reason, had moved to another constituency and had not yet been entered in the electoral roll of the new constituency, or was unable to visit the polling station for professional reasons or because of illness, due to advanced age, physical disability or otherwise because of his or her physical state, or was unable to do so without considerable difficulties. The reasons for being issued a ballot paper had to be plausibly stated.

The Court held that "the regulation of postal voting serves the purpose of achieving a voter turnout which is as high as possible, hence doing justice to the principle of general elections. It has hence repeatedly decided that the postal voting is constitutionally justified.

\footnotetext{
${ }^{11}$ Excerpt, full text of the decision is published on the website www.codices.coe.int.
} 
When amending the law on European elections, the legislator (...) reacted to the increasing mobility in today's society, as well as to the greater interest in individual lifestyles. It was guided by the goal of achieving the highest possible electoral turnout. According to the legislator, the obligation to make a plausible case for reasons preventing voters from voting in person had been practically useless. It was not possible to examine even a small sample of the reasons that were stated. Considering the decreasing willingness to cast votes in a polling station, it is comprehensible (...) that any attempt to tighten the requirements to give reasons or to regulate access to participation in postal voting by other means would risk causing further decline in voter turnout. (...)

There are currently no indications that the existing provisions of electoral law do not offer adequate protection against dangers which may be posed by implementing postal voting; namely dangers to the integrity of elections and to having secret and free elections. The legislator took account of the relevant constitutional requirements when reforming the law on European elections" (2 BvC 7/10 - 9 July 2013 ${ }^{12}$ ).

12 Summary available on the website http://www.codices.coe.int/NXT/gateway.dll/CODICES/precis/eng/eur/ ger/ger-2013-2-015. 